\title{
Phonological Adaptation of English Borrowings in the Egyptian Press with Reference to Al-Ahram Newspaper
}

Muhammad K. Assayyed

\section{Abstract}

The fact that the current influx of English borrowings is unprecedented in the history of Arabic generates lexical interference between both languages. This study aims at presenting a phonological analysis of the modifications in lexis this language contact brings about, by means of some linguistic techniques of inter-language adaptation. Essentially, the study shows how English loan words are phonologically adapted after they are transferred directly or indirectly into Arabic. By analyzing some selected editorials of Al-Ahram newspaper, the study concludes that the importation of new English loan words does not represent a threat for Arabic since the Arabic linguistic system has the ability to assimilate such new words by adapting them to its own structures.

Key words: English loan words, phonology, adoption, adaptation, Al-Ahram Newspaper.

\section{Introduction}

Arabic contains an extensive list of borrowings that has been transferred and integrated from English. If these items do not comply with the Arabic language paradigms, they will undergo some changes to make them fit better into Arabic. The process of adaptation, that words of English origin might have, can affect the morphology, phonology, semantics, and/or other grammatical categories of the borrowings in question. This process involves vast alterations in the structure of the borrowings, including assimilation, dissimilation, metathesis, elision, doubling, adding, deleting or replacing one or more segments of the original element, and modification of stress

(*) Assistant lecturer, Translation Program. Faculty of Arts, Sohag University, Egypt. 
patterns. By way of illustration, to a greater or lesser extent most English loan words inevitably undergo some phonological changes to be accepted as borrowings when they are transcribed into Arabic. The sources of these changes lie in the linguistic differences between both the donor and the borrowing language. In a nutshell, English is an Indo-European language, while Arabic is a Semitic language, and hence its linguistic system is very different from the English one. As a result, in order to incorporate a word from English into Arabic, certain changes usually need to be made.

\section{Review of the literature}

\subsection{Adaptation of English loan words}

According to Haspelmath (2009), "the source words of loanwords often have phonological, orthographic, morphological and syntactic properties in the donor language that do not fit into the system of the recipient languages" ( $p$. 42). In such situations of lack of fit, borrowings often undergo some modifications during the process of borrowing aiming at making them correspond with the recipient language patterns. These modifications, which are mostly referred to as adaptation or integration, are sometimes indispensable for Anglicisms to be usable in the borrowing language. As Pulcini (2011) reports,

in the borrowing process, however, this store of potentially shared vocabulary is often formally and semantically remodelled to suit the linguistic and expressive needs of the borrowing languages, so that many Anglicisms undergo several types of linguistic changes ... deviating from their English source words. (p. 437)

The adaptation of foreign elements into the replica language is more accurately measured by frequency of use, nativelanguage synonym displacement (i.e. the replacement of [an] existing word by a loanword), morphophonemic and syntactic assimilation (i.e. adaptation of borrowed elements to fit the 
phonological, morphological, and syntactic systems of the receiving language), and acceptability of the speakers.

\subsection{Phonological adaptation of English borrowings in Arabic}

Phonological adaptation is a process by which a language assimilates a borrowed element from its original native phonology to another phonological system. This process is made to Anglicisms in Arabic as a response to conform to the phonetic and phonological constraints in the Arabic sound system. Wells (2000) remarks that in the borrowing process

the incorporating of a loanword from one language into another may involve not only the sounds (phonetic segments, phonemics), of which the word's pronunciation is compared, but also the positions in which those sounds are used (syllable structure, phonotactics), the phonetic processes they undergo (phonological rules) and their accompanying suprasegmental features (duration, stress/accent). (p. 10)

Thus, two types of phonological adaptation of Anglicisms can be identified: the former is assimilation at the segmental (individual-sound) level in which exotic English phonemes are replaces [replaced] by familiar Arabic ones, and the latter is assimilation at the phonotactic (syllabic or prosodic) level, namely syllabic changes of Anglicisms in Arabic (i.e. sounds are arranged to fit Arabic phonotactics).

Broadly speaking, Arabic employs four fundamental strategies when borrowing an Anglicism into its native phonology. This is because of the inherent sound patterns in Arabic; for example, consonant clusters do not take place in syllable-initial position; there is a maximum of two successive consonants; and vowels do not take place in word-initial position. These four strategies are substitution, consonant lengthening, deletion, and epenthesis. In Arabic, these strategies are those most frequently adopted when compensations must be done to assimilate an Anglicism which 
contains English phonemes that are foreign to Arabic phonology. Very often, more than one assimilation process will and can take place within a phonological segment that needs more than one phonological change.

\section{Theoretical framework}

\subsection{Fantini's adoption vs. adaptation (1985)}

Fantini (1985) distinguishes between pure borrowing and adjusted borrowing. Pure borrowing occurs "when a word in language $\mathrm{X}$ was used in language $\mathrm{Y}$, retaining all of its native features", where $\mathrm{X}$ is a donor language and $\mathrm{Y}$ is a recipient language, and adjusted borrowing refers to patterns "borrowed from language $\mathrm{X}$ [and] adapted phonetically and/or morphologically into the system of language $Y "$ (p. 147). To put it simply, for Fantini, borrowing involves two processes: adoption and adaptation. Separating out these two different processes might be helpful in identifying and understanding the nature of borrowing.

\subsubsection{The adoption technique}

Adoption refers to the process of transferring patterns from a donor language as they are, i.e. borrowings should retain their meaning as well as their foreign pronunciation. According to Furiassi, Pulcini, and Gonzalez (2012), "if a loanword is imported without any formal change, it is referred to as adopted, non-adapted, unadapted, direct, primary, pure, integral, patent, or evident" (p. 12). Moreover, adopted borrowings are sometimes called foreignisms, because they are just copied from a donor language and pasted in a borrowing language. Examples of adopted borrowings can be seen in some French words, e.g. renaissance, souvenir, monologue, tableau, caricature that have been completely borrowed into English (where both form and meaning are transferred). 


\subsubsection{The adaptation technique}

Generally, the majority of loan words often undergo some changes during the process of borrowing. These changes, which are mostly referred to as adaptation or integration, are "sometimes indispensable for the word to be usable in the recipient language" (Haspelmath, 2009, p. 42). Therefore, when foreign elements are transferred from one language into another, they become adapted to their new linguistic context. Adaptation is a process in which the form of borrowed elements is assimilated by undergoing certain alterations aiming at making them correspond with the recipient language patterns. According to Furiassi et al. (2012), "if a loanword is changed -orthographically, phonetically, morphologically, semantically- in order to comply with the norms of the receiving-language system, it is referred to as adapted, integrated or assimilated" (p. 12). To illustrate, most suffixes of English loanwords do not fit the declension system of Arabic, and thus they are substituted for a native one, e.g. radicalism becomes /raadikaaliyya/.

Again, according to Fantini (1985), the penetration of a foreign word (or words) into the linguistic system of the borrowing language is a complex process. Due to this, sometimes, borrowings are adopted; at other times they are adapted. Additionally, adapted borrowings are partially assimilated or thoroughly assimilated. Therefore, borrowings should be defined within an adaptability scale in which linguistic elements differ in their level of integration to the borrowing language. According to the rate of integration, three different kinds of borrowing can be distinguished: completely adapted, partially adapted, and non-adapted words, i.e. adopted words.

\subsection{Katamba's direct and indirect borrowing (2005)}

This is a very basic distinction that can be made between different types of borrowings. Katamba (2005) asserts that 
borrowings can be introduced into a receiving language either directly or indirectly. "If a language takes a word directly from another ... we call what happens direct borrowing" (p. 135). This implies that, in direct borrowing, materials are transferred from a donor language to a borrowing language directly without any help from a third language. However, indirect borrowing occurs when a replica language receives a loanword from a donor language through another language.

According to Katamba (2005), "if a word is directly borrowed the chances of its undergoing drastic phonological modification are considerably less than those of a word that is indirectly borrowed" (p. 135). Therefore, in the case of direct borrowing, phonological and morphological aspects of borrowed elements are not much modified. For example, the English words genre, salad, and brochure, which appear the same in both French and English, have been transferred directly from French. However, in the case of indirect borrowing, borrowings undergo more phonological modifications from direct borrowing. For instance, the Arabic word /?al-jabr]/ was passed onto Spanish, and then it has been borrowed into English. Thus, algebra was indirectly adopted from Arabic, with Spanish as a mediator (Fromkin \& Rodman, 1993, p. 332).

\section{Methodology}

\subsection{Data collection and procedures}

One of the best ways to account for English borrowings into Arabic is to collect data from a specific set of newspapers. Therefore, in order to achieve the purpose of the current study, randomly selected articles of one of the most widely circulating Egyptian daily newspapers, [Al-Ahram], serve as the corpus of the study. 


\subsection{Suggested model for analysis}

Rogers (2004) mentions that "deciding which set of analytic procedures to use depends on the practical research situation you are in, the texts you are studying, and your research questions" (pp. 7-8). In brief, the nature of texts and research requirements determine the tools necessary for analysis. Thus, in order to highlight anglicisms in [Al-Ahram] corpus, Fantini's model (1985) is employed. In a nutshell, the model includes two analytical tools which are suitable for the nature of the study at hand. These tools are explained briefly in the subsequent section.

\subsection{Analytical tools}

\subsubsection{Adopted loan words}

As stated in 2.1. above, Fantini (1985) thinks that an adoption occurs "when a word in language $X$ was used in language Y, retaining all of its native features" (p. 147). In this respect, borrowings are just copied from the donor language and pasted in the recipient language, and thus they retain the same meaning and the same foreign pronunciation of the source word. Adoptions, known as transliterated, unadapted, direct, primary, or integral borrowings, are the easiest Anglicisms to identify in Arabic media discourse, since they appear in their original form or in a similar form.

\subsubsection{Adapted loan words}

Schultz (2012) asserts that adaptation is "used to designate the assimilation to which a word from a foreign language is subjected to make it fit into the system of the receiving language" (p. 49). Therefore, adapted Anglicisms are assimilated by undergoing certain alterations aiming at making them correspond with the recipient language patterns. 


\subsection{Procedures of data analysis}

To investigate the usage of English borrowings in Arabic, the analysis is carried out according to the following steps:

- The material for this study is collected from a range of 50 articles.

- Unfortunately, no software is capable yet of recognizing anglicisms in Arabic texts due to the problematic Arabic word boundaries which apply to all borrowings that have changed their appearance in Arabic. Therefore, articles were read through manually, and then any word thought to be of an English origin is extracted in order to compile a list of anglicisms. When presuming that a word is of an English origin, it is looked up in Abdel-Raheem's (2011) "Mu؟jam al-daxiil fi al-lugha al-@arabiyya al-hadiiea wa lahajaatiha" [Dictionary of loanwords in the Arabic language and its dialects]. If this dictionary indicates that the word originated in English or entered Arabic through English, this word is considered an anglicism. As a matter of fact, the dictionary does not contain all English borrowings, and hence this method may sometimes not be successful. In such cases, Onysko's (2007) definition of an anglicism is adopted, namely any "lexical and structural element that can be formally related to English" (p. 106).

- After that, the data are analyzed to show the major phonological changes that these borrowings have undergone in the process of adaptation into Arabic, using the IPA symbols.

- It goes without saying that a bulk of anglicisms are excluded from analysis, because of the following reason: some of them are names of things mentioned for the first time, and they are not active in Arabic such as names of people, names of geographic places, names of hotels, trade mark names, some internet websites, shops, and 
business places, e.g. companies, organizations, and supermarkets, etc.

- The current study does not investigate the origins of anglicisms. Some borrowings have French, German, or Italian origins and are transferred to English. Arabic has borrowed them from English not Italian, German or French.

\section{Analysis and Discussion}

To begin with, Al-Ahram corpus encompasses 2499 English loan words. These are classified using Fantini's model (1985). At the core of this model lies the distinction between importation and substitution. Importation refers to the introduction of a foreign item from English into Arabic, whereas substitution denotes the process of replacing an English item with a native pattern. Thus, the extent to which loan words are imported or modified by substitution of the borrowing language rules determines the classification of borrowings found in Al-Ahram corpus. Based on these criteria, Anglicisms can be classified into two different categories:

1) adopted English borrowings,

2) adapted English borrowings.

The distribution of borrowings across these two types is as follows: almost forty percent of the English elements found in the corpus have been taken over with little or no change in spelling and morphology. English borrowings are labeled adopted Anglicisms, if they appear in the text the way they would look in an English text or if they retain the same meaning and the same foreign pronunciation of the English word. This implies that some borrowings may not be labeled adopted Anglicisms, if they appear with an Arabic ending, for example, with a plural or a feminine ending. To be considered an adapted Anglicism, a loanword in Arabic must feature other characteristics which make it different from its English original, as in spelling changes such as /b/ instead of /p/ or 
typical Arabic plural or gender endings. The following table illustrates the frequency of the various Anglicism types in the corpus.

\begin{tabular}{|c|c|c|}
\hline Mechanism & Adopted loan words & Adapted loan words \\
\hline $\begin{array}{c}\text { No. of } \\
\text { Terms }\end{array}$ & 989 & 1510 \\
\hline$\%$ & $39.57 \%$ & $60.43 \%$ \\
\hline
\end{tabular}

Table 1: Types of Anglicisms

\subsection{Adopted English borrowings}

On the whole, adopted Anglicisms account for $39.57 \%$ of all Anglicisms found in the corpus. These include names of companies such as تويوتا /tuuyuuta/ (Toyota), جوجل/guugil/

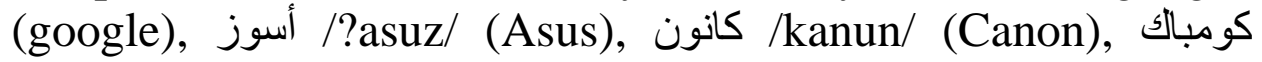
/kumbak/ (Compaq), إنتل /?intil/ (Intel), لينكس /linuks/ (Linux),

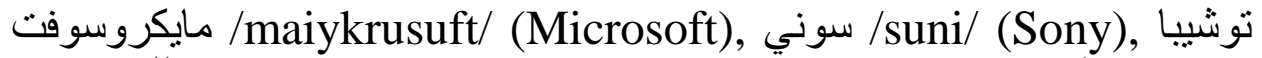

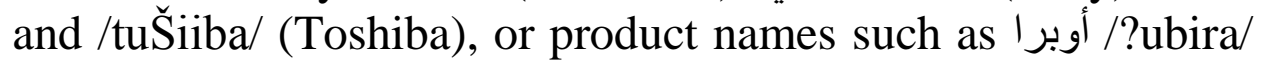
(Opera), بلايستيشن/blaaystaayŠan/ (Playstation), أيفون /?aiyfuun/ (iPhone), and ثينك باد /einkbaad/ (Thinkpad). It could be queried here, if it is really fair to include company and product names, but practically all of these are widely recognized and utilized in Arabic.

Proper names that have a meaning that goes beyond the object or place that they stand for are counted as adoptions. In addition, names of organizations and agencies that could be rendered in Arabic belong to this category. Equally important, the remainder of this category presents relatively pure Anglicisms, that is those words which have no change in their phonology or morphology. Examples of these include تويتر /twiitar/ (twitter), فاكس /faaks/ (fax), باهو /yahuu/ (yahoo), دافيتريا /kaafitirya/ (cafeteria), دولار/duulaar/ (dollar), إستيريو/2 /?istiiriyuu/ (stereo), ميكروويف/maiykruwiiv [maykruwiiv]/ (microwave), سيناريو /siinaaryuu/ (scenario), سيمينار /siminaar/ 
(seminar), كولسترول/kulisturuul/ (cholesrtol), أوزون /?uuzuun/ (ozone), روتين/ruutiin/ (routine), etc.

With regard to acronyms, most of them are categorized as adoptions. These include أب سي دي إل ICDL (international computer driving license), أيه أر تي ال ART (Arab radio and television), أي سي يو ICU (intensive care unit), سي في إني CV (curriculum vitae), إس إم إس إي SMS (short message system), تويفل TOEFL (test of English as a foreign language), فيفا FIFA (Fédération Internationale de Football Association), and RAM (random access memory). One might argue that some of these words are pronounced differently in Arabic, but the difference in phonology is only minimal and not obvious to Arabic speakers, but other Anglicisms which differ greatly are included in the category of adaptations.

\subsection{Adapted English borrowings}

Adapted Anglicisms account for almost $60.43 \%$ of all Anglicisms in the corpus. In contrast to adoptions, they have been assimilated to the Arabic spelling and morphological system. The reason for this high percentage is the large requirements of coining new terminology such as time, expertise, and some methods to make the new term popular. Therefore, the most suitable way is to borrow an Anglicism and adapt it to the phonological and morphological rules of Arabic. The process of adaptation, that Anglicisms might have, can affect the morphology, phonology, semantics, and/or other grammatical categories of the borrowings in question. As a result, in order to incorporate a word from English into Arabic, certain changes usually need to be made. Accordingly, the majority of Anglicisms in the corpus belong to the category of adapted Anglicisms.

\subsubsection{Phonological adaptation}

Obviously, phonological adaptations of borrowings reflect areas and effects of phonetic and phonological interference 
between English and Arabic. Arabic employs four fundamental strategies when borrowing an Anglicism into its native phonology. These strategies are substitution, consonant lengthening, deletion, and epenthesis.

Epenthesis, one of the most frequent mechanisms, is used to make borrowings comply with the syllable structure of the recipient language. It refers to the process of adding a vowel to make a word more pronounceable. Generally, epenthesis is employed to break up consonant clusters that present problems for Arabs in the pronunciation of some Anglicisms. For instance, Arabic has borrowed the Anglicisms plasma, plastics, platinum, and Pluto; phonetically /plæzmə/, /plæstık/, /plætınəm/, and /plu:tuəu/. Though English phonology and syllable structure allow English natives to place consonants /p/ and / $1 /$ next to each other, Arabs find this combination very difficult to pronounce without assimilation. Therefore, Arabs change the pronunciation by adding a vowel in between the consonants /p/ and /1/ resulting in the final pronunciation بلازما

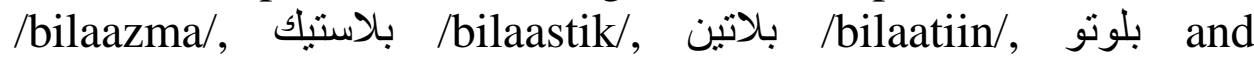
/buluutu/.

Another type of epenthesis is the prefixation of the prothetic syllable /?i/. The use of that prothetic syllable is motivated by the fact that Arabic phonology does not allow onsetless syllables and, also, does not allow consonantal clusters in the onset. The prothetic syllable insertion is employed, when borrowings begin with the sibilant/s/, e.g. /str-/, /st-/, /sk-/, etc. In order to split such consonant sequences, the prothetic syllable /?i-/ is prefixed before consonant sequences. Consider the following examples: ?istiraatiijiyyah/ for strategy, إستيرليني / إستر اتيجة sterling, أسبرين/?isbiriin/ for aspirin, أيس كريم/?iskiriim/ for ice cream, and إسكتش /?iskit ̌̌S/ for sketch.

Substitution is one of the adaptation processes by which a language substitutes one phoneme (speech sound) with another more familiar phoneme. Al-Jawaliqi (1966) suggests that Arabs 
often change loanwords ... by substituting foreign phonemes by their nearest homorganic Arabic equivalents. At times, they may replace foreign phonemes by heterogeneous (i.e., heterorganic) substitutes. It is imperative to accommodate such changes lest Arabic should be infiltrated by 'foreign' phonemes. (p. 6)

To illustrate, the English words parliament, plastic, Pepsi, and lamp which are phonetically written as /pa:limənt/, /plæstık/, and /pipsi/ are transferred into Arabic as برلمان/barlamaan/, بيسي and /bibsi/. Since the voiceless labial /p/ does not exist in Arabic phonology, it represents an accidental gap in Arabic phonology and orthography, and hence Arabic substitutes the unfamiliar /p/ with the more familiar /b/, which is a voiced labial sound. As a result, rather than pronouncing parliament, plastic, and Pepsi, as /pa:limont/, /plæstık/, and /pipsi/, Arabic speakers pronounce them as /barlamaan/, /blaastik/, and /bibsi/. Other examples are بنطلون/bantaluun/ for pantaloon, بنسيلين/binsiliin/ for penicillin, بترول/bitruul/ for petrol, بيتز /bitza/ for pizza, بوليس and /buliis/ for police in

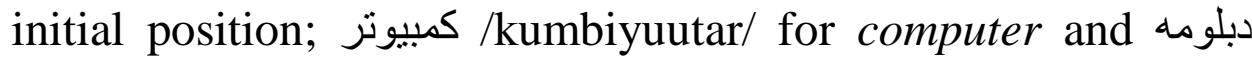
/dibluuma/ for diploma in medial position; and /bub/ for pop and /lamba/ for lamp in final position.

In a similar way, substitution is elicited in the change of the voiced velar stop /g/ in some Anglicisms into the voiced uvular fricative /gh/ as in photograph pronounced in Arabic as مغناطيس /futughraaf/, magnet pronounced as فونوغراف /maghnatiis/, and telegraph pronounced as تليغر اف/tillighraaf/. Similarly, the English voiced labiodental fricative /v/ exists in English as a phoneme but it does not exist in Arabic as a distinct phoneme, and hence it represents an accidental gap in Arabic phonology. As a result, this sound is changed into the labiodental fricative /f/. Some examples are تليفزيون/tilifizyuun/ for television, فكتوريا /fakturia/ for Victoria, فيز /fiiza/ or /viza/ for visa, سفن أب /sifin ?ab/ or /sivin ?ab/ for seven up, فيلا and فيلا / /filla/ for vela, بلف /balf/ for valve. In short, /v/ which is 
phonemic in English is significant, because it affects the meaning, and this is very clear in the minimal pair van and fan, but in Arabic it does not affect meaning.

One of the recurrent phonological patterns in Arabic is consonant lengthening or doubling which is referred to as gemination. Blanc (1952) suggests that gemination is "the prolongation of the continuants and a longer closure of stops" (p. 73). In point of fact, geminates are so numerous in Arabic and occur word-medially and word-finally. For instance, the English word battery, which is phonetically written as /bætəri/, is pronounced in Arabic as بطارية/battaariyyah/. Other Anglicisms, which undergo gemination to approximate Arabic, are دوريلا /ghurilla/ from gorilla, دانتيلا /dantilla/ from dentelle,

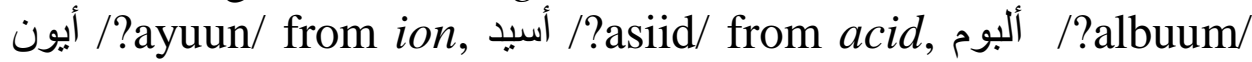
from album, ميلمتر /millimitr/ from millimeter, ميلتزم and /millilitr/ from milliliter.

Another process of the adaptation of Anglicisms in Arabic is deletion. Smeaton (1973) suggests that some borrowings undergo syllabic deletion in order to facilitate the pronunciation of foreign words or in order to cope with the Arabic tri- or quadri-consonantal root structure, "trimming away consonants and syllables but a representative portion of the original term is left" (p. 86). In other words, deletion is the process of completely omitting a sound that makes an Anglicism too difficult to pronounce. To illustrate, Arabic has borrowed the word circus from English, but Arabs have trouble pronouncing it correctly due to the syllable that takes place at the end of the word. By using the process of deletion, Arabic assimilate circus from its original form to سيرك /sirk/ by completely removing the final syllable. This simple consonant removal allows the elimination of a consonant cluster, therefore fitting the established Arabic syllable structure allowance. 


\section{Conclusion}

This paper investigates the phonological characteristics of words of English origin transferred into Arabic. It examines the phonological processes that occur when words are incorporated directly or indirectly from English. More specifically, this paper shows how Arabs assimilate English words through the processes of substitution, deletion, and epenthesis to ease the pronunciation of foreign items. The exploration of phonological assimilation enhances the understanding of the phonological modifications that numerous English loan words undergo during the process of borrowing. These adaptations reveal aspects of Arabic phonology, such as vowel harmony, and their implications on borrowings. The findings of the study show that assimilations of borrowings are not random, and that loanword phonology provides a clear picture of what the systematic mechanisms that native Arabic speakers utilize look like.

\section{References}

Abdel-Raheem, F. (2011) Mu؟jam al-daxiil fi al-lugha al؟rabiya al-hadiea wa lahajatuha [Dictionary of loanwords in the Arabic language and its dialects] City: Publisher?

Al-Jawaliqi, M. (1966). Al-mu؟arrab min al-kalam al-؟ajami

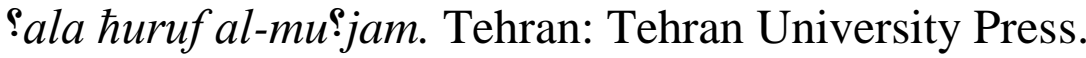

Blanc, H. 1952. Studies in North Palestinian Arabic. Jerusalem: Central Press.

Fantini, A. (1985). Language Acquisition of a Bilingual Child: A Sociolinguistic Perspective (To Age Ten). England: Multilingual Matters LTD.

Fromkin, V. \& Rodman, R. (1993). An Introduction to Language (5th ed.). New York: Holt, Rinehart \& Winston.

Furiassi, C., Pulcini, V. \& Gonzalez, F. (2012). The lexical influence of English on European languages: From words to phraseology. In C. Furiassi, V. Pulcini \& F. Gonzalez, 
(Eds.), The Anglicization of European Lexis (pp. 1-26). Amsterdam and Philadelphia: John Benjamins Publishing Company.

Haspelmath, M. (2009). Lexical borrowing: Concepts and issues. In M. Haspelmath \& U. Tadmor (Eds.), Loanwords in the World's Languages: A Comparative Handbook (pp. 35-54). Berlin: Mouton de Gruyter.

Katamba, F. (2005). English Words: Structure, History, Usage. New York: Routledge.

Onysko, A. (2007). Anglicisms in German: Borrowing, Lexical Productivity, and Written Codeswitching. Berlin \& New York: Walter de Gruyter.

Pulcini, V. (2011). Much the same meaning: Semantic integration of Anglicisms in Italian. In G. Martino \& S. Nuccorini (Eds.), Challenges for the $21^{\text {st }}$ Century: Dilemmas, Ambiguities, Direction. Papers from the 24th AIA Conference, Vol. II: Language Studies. 437-445. Roma: Edizioni Q.

Rogers, R. (2004). An introduction to critical discourse analysis in education. In R. Rogers (Ed.), An introduction to critical discourse analysis in education (pp. 1-18). London: Lawrence Erlbaum Associates Publishers.

Schultz, J. (2012). Twentieth Century Borrowings from French to English: Their Reception and development. Cambridge:

Cambridge Scholars Publishing.

Smeaton B. H. (1973). Lexical Expansion Due to Technical Change. Bloomington: Indiana University Publications.

Wells J.C. (2000). Overcoming Phonetic Interference. English Phonetics: Journal of the English Phonetics of Japan, 3, 9-21. 